DOI: $10.20472 /$ TE.2018.6.1.005

\title{
STRATEGIC APPROACH TO PEOPLE MANAGEMENT IN EDUCATIONAL ORGANISATIONS (EXAMPLE OF THE CZECH REPUBLIC)
}

\section{MICHAELA TURECKIOVÁ}

\begin{abstract}
:
Educational organisations constitute a specific and internally heterogeneous group of work organisations. They differ from other types of organisations by the subject of their activity and hence by the mission of their existence and also by the requirements on managers not only in the domain of people management, but also as regards managers' roles and competencies. This study deals first with the definition of a strategic approach to work with people in this type of organisations, including an overview of selected models of human resource management. It then demonstrates on them what are the preconditions for incorporation of personnel work into the system of organisation management and how can personnel work be carried out in a systematic and strategic manner. It follows with a summary of basic facts on educational organisations in the Czech Republic, including specific requirements on continuous education for managers of these organisations. This education should eliminate deficits in capabilities of educational managers and enable them to cope efficiently with their roles. Finally, it presents results of an empirical survey among managers of educational organisations in the Czech Republic who studied the subject of educational management at the Faculty of Education of the Charles University (Prague) in the period 2014-2016.
\end{abstract}

\section{Keywords:}

People management, human resource management (HRM), HRM models, educational organisation, educational management, survey.

JEL Classification: 129, M12

\section{Authors:}

MICHAELA TURECKIOVÁ, Charles University, Faculty of Education, Centre of School Management, Czech Republic, Email: michaela.tureckiova@pedf.cuni.cz

\section{Citation:}

MICHAELA TURECKIOVÁ (2018). Strategic Approach to People Management in Educational Organisations (Example of the Czech Republic). International Journal of Teaching and Education, Vol. $\mathrm{VI}(1)$, pp. 71-84., 10.20472/TE.2018.6.1.005 


\section{Introduction}

Educational organisations constitute a specific group of work organisations. Their integrating elements include their mission, the attainment of educational goals and the development of learning (Průcha, 2015). Educational organisations fulfil a numbern of functions and traditionally have a specific, albeit not incontestable, position in the society. Employees of educational organisations focus their interest on various types of recipients of education to whom they provide education throughout the length and width of their life, enabling them to gain and develop key competencies for life, including learning competencies (in more detail for instance Veteška, Tureckiová, 2008).

At the same time, these organisations also differ among themselves with the differences depending on whether they are part of a "backbone" formal system of education and the demands placed on their managers. Educational managers (head teachers and other managers of schools and school facilities) constitute one of a few professional groups for which continuous education and professional development are statutory obligations. A substantial part of these managers receives management education only in the course of their work in managerial positions. Education in strategic management, including strategic approach to people management have become part of professional development for this group of managers only recently.

\section{Strategic approach to people management}

An approach of managers which puts emphasis on a personal dimension of management tends to be described as people management (Urban, 2003). People management can be defined also as concept "in which the organization...focuses on the development of staff; it also examines ways of identifying and assessing training needs and performance requirements and how they relate to the needs and requirements of the organization" (Tureckiová, 2009, p. 51). According to McPheat (online) "people management encompasses the tasks of recruitment, management, and providing ongoing support and direction for the employees of an organization. These tasks can include the following: compensation, hiring, performance management, organization development, safety, wellness, benefits, employee motivation, communication, administration, and training".

It can be deduced from the above definitions that the term "people management" has begun to replace the term "human resource management". According to Armstrong and Taylor (2015, p. 43) human resource management is „a managerial approach to using people's efforts, abilities and dedication in order to perform required work in a manner ensuring good prospects for an organisation". This definition suggests a link between a general strategic management of an organisation and the concept of human resource management as „a strategic, integrated and comprehensive approach to employment, development and satisfaction of needs of the people working in an organisation“ (ibidem, s. 47). Sahoo (2016, online) states that „strategic human resource management is a process that involves the use of overarching approaches to the development of HR strategies, which are integrated vertically with the business strategy and horizontally with one another. Strategic HRM defines the organization's intentions and plans on how its business goals should be achieved through people". 
Strategic human resource management is defined similarly also by Armstrong and Taylor (2015. p. 57, p. 60): "Strategic human resource management is a specific approach to the development and implementation of human resource strategies which are integrated with the strategy of an organisation and support the attainment of the organisation's strategic objectives. The strategic human resource management is an approach based on certain concepts rather than on particular procedures. It encompasses adoption of strategic decisions and identification of strategic priorities. The essence is an agreement between the strategy of an organisation and its human resource strategy."

The primary goal of strategic HRM is to execute the business strategy across the human resource activities. This requires identifying key HR areas where strategies can be implemented in the long run to improve the overall employee motivation and productivity (Sahoo, 2016, online).

The application of people management systems requires that individual HR activities are integrated into the system which should lead to the attainment of strategic objectives of an organisation (Šikýř, Borovec \& Lhotková, 2012, p. 20). An overview of key HR activities is given by Bláha et al. (2013) - see Figure 1. This overview of course can not cover specifics relevant for particular types of work organisations. Currently, the application of strategic approach to people management is becoming a priority also for educational organisations, in particular in the area of strategic planning.

Figure 1: Key HR activities at a strategic management level

\begin{tabular}{|c|c|c|c|c|}
\hline $\begin{array}{l}\text { The level of } \\
\text { HRM }\end{array}$ & $\begin{array}{l}\text { Selection of } \\
\text { employees and } \\
\text { their placement }\end{array}$ & $\begin{array}{l}\text { Remuneration } \\
\text { (wages or } \\
\text { salaries, } \\
\text { employee } \\
\text { benefits) }\end{array}$ & $\begin{array}{l}\text { Employee } \\
\text { appraisal }\end{array}$ & $\begin{array}{l}\text { Development } \\
\text { of employees }\end{array}$ \\
\hline \multirow[t]{3}{*}{$\begin{array}{l}\text { Level of } \\
\text { strategic } \\
\text { management }\end{array}$} & $\begin{array}{l}\text { Specification of } \\
\text { the profiles of } \\
\text { employees } \\
\text { needed for the } \\
\text { operation of the } \\
\text { organisation in } \\
\text { the long term }\end{array}$ & $\begin{array}{l}\text { Setting up of a } \\
\text { loyalty } \\
\text { programme } \\
\text { comparable in } \\
\text { domestic as well } \\
\text { as international } \\
\text { framework }\end{array}$ & $\begin{array}{l}\text { Determination of } \\
\text { the level and } \\
\text { type of } \\
\text { performance } \\
\text { which is } \\
\text { essential for the } \\
\text { growth of the } \\
\text { organisation }\end{array}$ & $\begin{array}{l}\text { Setting up of a } \\
\text { general } \\
\text { programme for } \\
\text { the development } \\
\text { of the } \\
\text { organisation's } \\
\text { management }\end{array}$ \\
\hline & $\begin{array}{l}\text { Analysis of } \\
\text { migration flows } \\
\text { taking into } \\
\text { account future } \\
\text { changes in } \\
\text { labour } \\
\text { availability }\end{array}$ & \multirow[t]{2}{*}{$\begin{array}{l}\text { Introduction of a } \\
\text { remuneration } \\
\text { system which is } \\
\text { linked with } \\
\text { strategic } \\
\text { objectives of the } \\
\text { organisation }\end{array}$} & $\begin{array}{l}\text { Determination of } \\
\text { fair performance } \\
\text { criteria }\end{array}$ & $\begin{array}{l}\text { Preparation of a } \\
\text { programme for } \\
\text { the development } \\
\text { of employee } \\
\text { flexibility, } \\
\text { necessary for } \\
\text { adaptation to } \\
\text { change }\end{array}$ \\
\hline & $\begin{array}{l}\text { Investigation of } \\
\text { development } \\
\text { trends in labour } \\
\text { and labour } \\
\text { market }\end{array}$ & & $\begin{array}{l}\text { Evaluation of } \\
\text { the fulfillment of } \\
\text { long term } \\
\text { objectives of the } \\
\text { organisation }\end{array}$ & $\begin{array}{l}\text { Planning of } \\
\text { professional } \\
\text { development for } \\
\text { employees }\end{array}$ \\
\hline
\end{tabular}


The application of people management within an organisation requires a combination of a systemic and strategic approach to management. This approach must be in agreement with a competitive strategy, take into account the internal as well as external environment of the organisation and comply with the interests of stakeholders (Šikýř, 2014, p. 23).

\section{Strategic models for human resource (people) management}

Strategic models for human resource management (people management) have been gradually emerging since 1980s. These models focus simultaneously on the attainment of the organisation's objectives and respect the need of an efficient performance of personnel work in conformity with strategic objectives of the organisation (Heinová, 2010, p. 11). Currently, there is a considerable number of such models. Through these models, various theoreticians strive to describe the concept of human resource management or of strategic approach to people management.

In the Czech Republic, the following are the most widely known models of strategic HRM (people management): The Michigan/Matching Model, The Harvard Model, The European Model, Competency-based HRM Model (see Veteška \& Tureckiová, 2008; Tureckiová, 2009; Šikýř, Borovec \& Lhotková, 2012; Šikýř, 2014; Armstrong \& Taylor, 2015, and others).

The Michigan/Matching Model (Fombrun et al., 1984; in Armstrong \& Taylor, 2015, s. 52) establishes the need to connect human resource management with the organisation's strategy. This determines a fundamental task for management to bring into agreement the organisation's structures with its system of human resource management so that they support the achievement of the organisation's strategic goals. Hence, the basic precondition for a successful application of this model is the achievement of an agreement between strategy, structure and the HRM system, taking into account the effect of the environment (Šikýř, 2014, s. 34). This model deals also with mutual interconnection of all major personnel activities. Also in this model, strategically important personnel activities include the selection of capable and motivated employees, their fair appraisal linked with the development of their potential and with remuneration (compare also with the above overview of key personnel activities on Figure 1, which, however, is not based only on the Michigan Model).

According to this model, the main purpose of strategic approach to people management is the possibility to influence capabilities, motivation, conditions and performance of staff in order to achieve strategic goals of an organisation. "An agreement between the strategy, the organisational structure and the system of personnel activities is a pre-condition for achieving the expected performance" (Šikýr et al., 2012, s. 18). The Michigan Model underlines the importance of human resource management for the success of an organistion, with this management having a fundamental effect on the performance of staff as well as of the whole organisation.

The determination of criteria for work performance, its measurement and evaluation have been for a long time difficult in the practice of educational organisations. Additional specifics (especially concerning staff selection and remuneration) are mentioned in the section dealing with outputs from the completed survey. On the other 
hand, educational organisations put a great emphasis on continuing professional development of their staff and the role of their managers in this development (for more details see Tureckiová, 2016).

The Harvard Model (Beer et al., 1984; in Armstrong \& Taylor, 2015, p. 53) is a model which explicitly defines human resource management as a competence of all managers, from top managers to line managers. For the purposes of this study and for the application of a strategic approach to people management it can be derived from this model that "human resource management encompasses all decisions and all activities of managers which influence relations between an organisation and its employees" (ibid). Šikýr (2014, p. 37) then on the basis of this model specifies that the principles and procedures applied in human resource management are influenced by the interests of stakeholders and by situational factors from within as well as outside of the organisation. On the other hand, the principles and procedures applied in human resource management in a particular organisation lead to outputs from work activities and staff behaviour and to the overall results of the whole organisation.

Compared with the previous model, the application of the Harvard Model in the setting of objectives and methods of people management puts a greater emphasis on the interests of stakeholders and on the analysis of the effects of factors within and well as outside of the organisation. People management is further expected to lead to the development of staff commitment, to the development of its capabilities and to an agreement between the goals of the staff and those of the organisation (Šikýř, 2014, p. 38).

The Harvard Model draws attention to the interests of stakeholders, which in the case of educational organisations include especially the statutory authorites (for school organisations), or more generally the owners, the participants in the education and other groups which have interest in the attainment of educational goals, in the content of the education and at the same time have influence on the existence and successful functioning of educational organisations. The latter include also important decision makers, such as creators and promoters of educational policy and more general public policy makers. Also for this reason, analyses of stakeholders and other strategic analyses of internal and external environment should be a part of strategic management, planning and decision-making by managers of educational organisations.

The Guest's four main strategic objectives, developed on the basis of the Harvard Model also provide inspiration for the application of a strategic approach to people management in educational organisations. This concerns in particular the strategic integration, i.e. a combination of human resource management with strategic plans of the organisation. It further includes the objective of high commitment and identification of the employee's interests with those of the organisation; managers' behaviour and the ability to incorporate innovations (Vojtotič, 2011, p. 160). However much it is in reality difficult to connect the goals of an organisation with those of individuals, the segment of educational organisations is traditionally among those, where employees tend to be for a great part or totally identified with the goals of their organisation, or with the functions of an educational organisation and its culture (for more details see for instance Eger, 2006). 
The European Model (Brewster, 1993; in Armstrong \& Taylor, 2015, s. 54) is the most recent of the models described here. As follows from its name, this model takes into account the specific European context, i.e. especially established legal environment, goals of an organisation, their social responsibility, relationships among employees and links between people management specialists and other managers. The European model can thus be described also as a transfer of American models of strategic HRM into European conditions, where differences of European cultures are manifested and support goes rather to group interests than to individual interests. Also this model puts emphasis on an agreement between the organisation's strategy and people management strategy and encompasses important influences from the organisation's external environment (Šikýř, 2014, s. 39-40).

For educational organisations which themselves constitute a specific and internally differentiated group of work organisations, the important factors from macroenvironment are especially demographic and socio-demographic, cultural, structural (the structure of educational organisations in the region) and interest in lifelong learning. The use of ICT, research and development in the region, with implications for the functioning and development of educational organisations, are emphasised among the technological factors. As regards economic factors, the financing of educational organisations and the remuneration of pedagogical as well as non-pedagogical staff are prominent factors. Prices of products and services which educational organisations need for their functioning also have an effect on them. Legal and legislative factors are linked with the execution of political power and with changes in education laws (Báča, 2007, online). In order to assess the effect of the above factors, managers of educational organisations need to know the situation not only in their region and to cooperate with stakeholders.

The Competency-Based Management Model (Rothwell \& Dubouis, 1984; in Tureckiová, 2009) is, in the Czech Republic, the most widely known and popular model representing a strategic approach to people management. In Czech domestic literature it tends to be described also as human resource management according to competencies or as integrated human resources management. It is evident from all the alternative names that people management is integrated into the managing processes of an organisation (the so-called vertical integration) and that all major personnel activities are at the same time interconnected (the so-called horizontal integration) (Bartoňková, 2010). By this description, this author in essence builds on Armstrong (1999 and 2007, as quoted by Veteška \& Tureckiová, 2008, p. 83), which states that competency-based human resource management is a system of management bringing together strategic personnel processes which include recruitment and selection of employees, and education, development and appraisal of employees. These processes are then combined into one whole, with the system of competencies as an integrating element.

According to Bartoňková (2010) and Plamínek \& Fišer (2005; authors of a Czech version of a methodology for management by competencies), this model can be defined also as an approach to people management and to the management of a whole organisation, which is based on harmony between the area of human resources and the area of human labour. 
The term "competence" as such is one of the fundamental terms in educational theory and practice, and the development of overviews of required competencies belongs to key activities of management in educational organisations. The importance of competences is emphasised also by Prusak (2016), who writes that „competences are specific expression of the potential of employees and their ability, in this new context will become of increasing importance. The key factor that determines the degree of utilisation of the individual competences of the particular person, is the level of motivation and attitudes to the defined tasks".

All the above models of strategic human resource (people) management represent in the implementing phase a shift to one of the basic forms of strategic approach to people management. The current form of people management aims for a desirable combination of a hard and a soft approach. This can be documented among others also by the requirement to connect "hard" factors of strategic management (such as strategy and structure of an organisation and achievement of the organisation's goals) with "soft" factors (cukture of the organisation, goals of individuals and support for the development of individuals and teams). All this while at the same time taking into account the effects of external environment and stakeholders' interests. Needless to say, all these aspects are discussed also within educational organisations.

The need to apply strategic thinking and management in educational organisations (particularly schools) had emerged in the Czech Republic in early 1990s (Báča, 2006, s. 71). This was connected with overall changes in the society and with a gradual, but at the same time considerably fast decentralisation of the education system. Not only organisations providing adult education or institutions of leisure education, but also schools had become part of a competitive market environment. Given the considerable autonomy of their top management, there has been since those times a continuous need to develop managerial competences of the schools' top management and more recently also of their wider management.

\section{Basic information on educational organisations in the Czech Republic}

Schools as well as other organisations whose basic activity is to provide educational activities to a wide spectre of participants are referred to as educational organisations in this text. The diversity of the participants (not only pupils and students) is given by their age (the dimension of lifelong education), but also by their educational goals and objectives (dimension of lifewide education). Various educational organisations also differ by the dominance of certain functions which they fulfil, not only in relation to the educational system, but also in relation to the society in general. Overall, it can be stated that for educational organisations which provide primarily education for children and adolescents, the functions concerned are educational, pedagogical, socializing, protective and professionalising. On the other hand, organisations providing education to adults and elderly primarily in the framework of non-formal education perform for instance recreational, retraining, developmental and acculturational function (Prücha, ed., 2009, and Průcha \& Veteška, 2012). An overview of the types of organisations taking part in education in the Czech Republic is shown in Figure 2: 
Figure 2: Educational organisations and other organisations providing education Initial education Continuing education

\begin{tabular}{|c|c|}
\hline \multicolumn{2}{|c|}{ Non-formal education } \\
\hline $\begin{array}{l}\text { Profit and non-profit } \\
\text { organisations } \\
\text { Schools and school } \\
\text { facilities }\end{array}$ & $\begin{array}{c}\text { Private commercial educational institutions } \\
\text { Employers } \\
\text { Non-profit organisations } \\
\text { Professional chambers, associations } \\
\text { Schools }\end{array}$ \\
\hline \multicolumn{2}{|r|}{ Formal education } \\
\hline $\begin{array}{c}\text { Universities } \\
\text { Tertiary technical schools } \\
\text { Secondary schools } \\
\text { Elementary schools } \\
\text { Kindergartens }\end{array}$ & $\begin{array}{c}\text { Universities } \\
\text { Tertiary technical schools } \\
\text { Secondary schools } \\
\text { (Elementary schools) }\end{array}$ \\
\hline
\end{tabular}

Source: Dvoráková (2015, p. 15) - modified

As follows from the above graphical overview, schools of different level, specialisation and differing also by their statutory authority (state, private person, church, municipality or an association of municipalities) constitute the basic type of educational organisations in the Czech Republic. In accordance with applicable legislation (Education Act), school facilities are also typical educational organisations. Other organisations can provide education as their main activity (educational agencies, independent educators of adults, international and multinational commercial organisations as well as non-profit educational organisations) or provide education to their members (industry associations or chambers) or provide the so-called statutory education to their employees (companies or employers in general) (for more details see Dvořáková, 2015, p. 9-15).

Similarly as in other countries, also in the Czech Republic schools and school facilities are the primary organisations considered as educational organisations. According to the statistics of the Czech Ministry of Education, Youth and Sports, there are approximately 11000 schools and school facilities in the Czech Republic (MŠMT Souhrn ČR, 2017, online). An accurate number of other educational organisations is not known. Just the number of educational organizations for adult education is estimated to range between 1000 and 2000 organisations (Palán, 2003).

Based on the number of their employees, most of the organisations for which education is their primary activity are small or medium-sized enterprises. They can be financed from private or public sources (for more details see Průcha, ed., 2009). 
Higher education institutions and universities constitute an exception as regards the number of employees and the application of a strategic approach to people management and they were not included in the survey described below (from among Czech authors, for instance Šafránková, 2016 deals with education management in tertiary education).

In view of the issues studied in this text, it needs to be stated that requirements concerning qualification and further professional development differ markedly between managers of schools and school facilities and managers of other educational organisations. Managers of schools and school facilities are at the same time educators and must have a master degree in pedagogical disciplines. Moreover, they are obliged to complete a specialised course in managerial disciplines, including people management, within two years of taking up the position of a top manager of a school or school facility. None of these obligations applies to managers of other educational organisations. Managers of most other educational organisations, especially those which provide continuing professional education for adults tend to be usually graduates of at least bachelor degree studies. Optionally, they can also complete public/business administration studies and rather exceptionally master degree studies in strategic HRM. If they are at the same time lecturers, they can also obtain a partial qualification as a lecturer in continuing education (Lektor dalšího vzdělávání, online).

Other specifics of school educational organisations rest in the fact that they tend to be described by technical literature also as institutions (they represent education as an important social institution), communities and networks of relations (Pol, 2007). Compared with other employing organisations, there are also differences in relationships between representatives of educational organisations and major stakeholders (especially political representation at state and regional level and statutory authorities). Head teachers of schools and school facilities are managers with considerable responsibilities as well as powers. Although they are top managers, they are often responsible also for operational management, and as mentioned before, they themselves perform educational activity. According to Rymeš (in Tureckiová, 2013, p. 69), head teachers are "in the position of a general manager with duties of a foreman". Differences can be found also in the roles of managers of educational organisations in the strategic development of the basic group of employees (i.e. teachers and other educators/lecturers) as written by Tureckiová (2016).

According to Báča (2006), schools as educational organisations are also specific by their culture. They are organisations bringing together adults, children and adolescents. "A successful school manager has to follow and assess consequences of changes in external and internal environment and has to be able to evaluate their impact on the steering of the school and on the education process" (Báča, 2006, p. 70). In view of the specifics, it is important to set a human resource strategy. "A comprehensive human resource strategy, resulting from the strategy of the school, defined a long-term policy for the management of employees, especially optimal ways for their recruitment, use and development for the attainment of strategic objectives (Šikýř Šikýřr, Borovec \& Lhotková, 2012, p. 22). To this one can add that within the selection procedure, prospective head teachers have to submit a proposed strategy for the development of the school they wish to manage. 
From the responsibilities of head teachers of schools and school facilities and from their position at the top of the organisational pyramid, it could be deduced that they would be active and competent carriers of the organisation's strategic management, including the application of a strategic approach to people management. At the same time, it needs to be mentioned that strategic management is not included in the specialised course for school managers.

\section{Summary and discussion of the results of a survey}

A survey focusing on the application of a strategic approach to people management in educational organisations in the Czech Republic took place in 2014 - 2016 on a sample of 147 educational managers and prospective educational managers, students of a 2-year master degree programme in Educational Management at the Centre of School Management at Charles University in Prague.

Figure 3: Research sample

\begin{tabular}{|l|l|l|l|l|}
\hline \multirow{2}{*}{ Year } & \multicolumn{2}{|c|}{ Number of respondents } & \multicolumn{2}{c|}{ Type of educational organisation } \\
\cline { 2 - 6 } & \multicolumn{2}{|c|}{ Male } & Female & \multicolumn{2}{c|}{ School } & Non-school \\
\hline 2014 & 14 & 30 & 27 & 17 \\
\hline 2015 & 7 & 52 & 39 & 20 \\
\hline 2016 & 6 & 38 & 33 & 11 \\
\hline
\end{tabular}

Source: Own

A qualitative research strategy was chosen and the techniques applied included moderated discussions, individual interviews and focus groups (for more details on the applied research strategy see Hendl, 2005).

The survey brought answers to the following research questions (RQs):

RQ1: Which models of people management are applied by the managers of educational organisations?

RQ2: What are the most important preconditions for the application of strategic approach to people management in the practice of educational organisations?

RQ3: What are the most important barriers (challenges) for the application of strategic approach to people management in the practice of educational organisations?

Based on the research survey, the respondents use or intend to use two of the aforementioned strategic models of people management, namely competency-based management and the Michigan/Matching model. The latter is used only in some $20 \%$ of the surveyed educational organisations, more frequently those which deal with continuing education and adult education.

Of the other concepts which could meet the characteristics of a strategic approach to people management, the respondents mentioned continuing professional development of staff (schools and school facilities), succession planning 
(organisations in the segment of adult education), diversity/age and/or talent management.

According to Prusak (2016, online) competency-based management is a modern approach in the context of intellectual capital and other components and linking of business resources. Its ingredients are important part of the strategic consideration that are carried out by the managerial staff in modern enterprises. Competencies themselves which constitute a specific expression of the potential of employees and their ability, gain in importance in this new context. The key factor that determines the degree of utilisation of individual competencies of the particular person, is the level of motivation and attitudes to the defined tasks (ibidem).

According to the respondents, the dominant position of the competency-based management model is at least partly caused by the ongoing reform of the Czech education system which uses the term competency as one of the key concepts. Besides, the competency-based approach eliminates shortcomings of other approaches because it targets the behaviour of workers. It is based on the development of competencies of staff according to the organisation's needs and requirements in conformity with its strategic objectives. Competency-based model is an effective tool for the selection, evaluation, development and education and, as the case may be, remuneration of staff. These conclusions obtained from respondents are also confirmed in specialist literature (e.g. Bartoňková, 2010; Veteška, 2010; Cimbálníková, 2013 and others).

The application of the Michigan model is also connected with a strategic approach to organisation management. The respondents which indicated that they use this model are aware of this feature. This model's undeniable advantage is that it is explicitly based on the requirement of conformity between the organisation's strategy, its structure and people management system of the one hand and the use of results from a strategic analysis on the other.

According to the respondents in the survey, the following belong to the most important preconditions (arranged into clusters) for a successful application of a strategic approach to people management in the practice of educational organisations:

- Socio-cultural, economic and legislative external conditions (managers of educational organisations are also aware of the effect of educational environment. Nevertheless, they have not mentioned it so often and have not provided examples of its possible analyses)

- Different concepts of effective management in different types of educational organisations (emphasis on performance management cycle in non-school educational organisations, emphasis on individual professional development plans in schools and school facilities)

- Knowledge of strategic management and strategic human resource management concept and models in different types of educational organisations (earlier assumption of the knowledge and use of strategic management by the head teachers of schools and school facilities has not been confirmed)

- Decision makers and decision making processes (directors of schools and school facilities are the main decision makers in the area of people management; on the other hand, in other educational organisations the decision-making and 
executive powers in this area are more often decentralised and delegated to all levels of management)

- Size, ownership and organizational structure of concrete educational organisation.

Among the main barriers for the application of a strategic approach to people management in the practice of educational organisations the respondents most frequently mentioned the following aspects:

- Lack of qualified staff and/or candidates (the position of an employee in an educational organisation and the profession of teacher in particular is not among the most sought-after in the Czech Republic, especially as concerns schools and school facilities, and this is caused also by salary conditions)

- Aging of teachers and managers in schools (average age of $50+$; this is connected with the previous point and with a lack of opportunities for development and more significant changes in carrier)

- $\quad$ Financing and market conditions (besides the previously mentioned salary factor, this is connected with overall situation in financing sources especially for schools and school facilities; the possibility of financing from EU funds has received mixed assessments, some respondents refer to "distortion of conditions")

- Legislation (rapid changes in the segment of schools and school facilities vs. lack of changes in continuing education and in educational organisations providing education to adults and elderly)

- Unsystematic professional development (this is among others connected with a low or inadequate offer of continuing education for educators and its uneven distribution among the regions of the country)

- Appraisal and evaluation processes (missing criteria in schools - this situation changed substantially in 2016; however, the survey could not take into account the new criteria of "good quality school").

\section{Conclusions}

Of the various models of strategic HRM (people management), the competency-based HRM model and the Michigan/Matching model are the most widely applied by educational managers in the Czech Republic. According to the respondents of the survey described in this text, the dominant position of the competency-based management model is at least partly caused by the ongoing reform of the Czech education system which uses the term competency as one of the key concepts. The survey identified main preconditions and barriers for the application of a strategic approach to people management in Czech educational organisations. It is intended to follow-up the survey with further investigations examining in greater detail the factors that would facilitate a successful application of strategic approach to people management in educational organisations in the Czech Republic. 


\section{Reference}

ARMSTRONG, M. \& TAYLOR, S. (2015). Řizení lidských zdrojů, moderní pojetí a postupy. Praha: Grada Publishing.

BÁČA, M. (2006). Vlastní hodnocení školy. Praha: Raabe.

BÁČA, M. (2007). STEP analýza. Retrieved from http://clanky.rvp.cz/clanek/s/Z/1127/STEPANALYZA.html/

BARTOŇKOVÁ, H. (2010). Firemní vzdělávání. Strategický prístup ke vzdělávání pracovníků. Praha: Grada Publishing.

BLÁHA, J. et al. (2013). Pokročilé řízení lidských zdrojů. Brno: Edika.

CIMBÁLNÍKOVÁ, L. (2013). Strategický rozvoj lidských zdrojů. Olomouc: Univerzita Palackého v Olomouci.

DVOŘÁKOVÁ, M. (2015). Management vzdělávání. In TROJAN, V., TURECKIOVÁ, M., TRUNDA, J. \& DVOŘÁKOVÁ, M. (2015). Př́stupy k managementu vzdělávání v kontextu České republiky. Praha: Univerzita Karlova v Praze, Pedagogická fakulta.

EGER, L. (2006). Řízení školy při zavádění školního vzdělávacího programu. Plzeň: Fraus.

HEINOVÁ, H. (2010). Rozvoj lidských zdrojů. Retrieved from cmkos.cz

HENDL, J. (2005). Kvalitativní výzkum v pedagogice. Retrieved from https://www.researchgate.net/profile/Jan_Hendl/publication/267848497_KVALITATIVNI_VYZKU M_V_PEDAGOGICE/links/580e17bd08ae0360753dc1d4/KVALITATIVNI-VYZKUM-VPEDAAGOGICE.pdf

Lektor dalšího vzdělávání (online). Retrieved from https://www.narodnikvalifikace.cz/kvalifikace-581Lektor_dalsiho_vzdelavani

MCPHEAT, S. (online). What is people management? Retrieved from http://www.fibre2fashion.com/industry-article/2235/what-is-people-management?page=1

MŠMT - Souhrn ČR (online). Retrieved from http://toiler.uiv.cz/rocenka/rocenka.asp

PALÁN, Z. (2003). Profesní vzdělávání 2002. Praha: MJF.

POL, M. (2007). Škola v proměnách. Brno: Masaryková univerzita.

PLAMÍNEK, J. FIŠER, R. (2005). Řízení podle kompetencí: Management by Competencies. Praha: Grada Publishing.

PRŮCHA, J. \& VETEŠKA, J. (2012). Andragogický slovník. Praha: Grada Publishing.

PRŮCHA, J. (Ed.) (2009). Pedagogická encyklopedie. Praha: Portál.

PRŮCHA, J. (2015). Česká vzdělanost. Praha: Wolters Kluwer.

PRUSAK, R. (2016). The impact of employee competencies management as part of the human capital on the intellectual capital implementing process. Retrieved from http://eds.a.ebscohost.com/ https://doi.org/10.1515/manment-2015-0022 
SAHOO, S. (2016). Strategic HRM Practices - Public Sector Perspective. The Journal of Institute of Public Enterprise. Retrieved from http://eds.a.ebscohost.com/

ŠAFRÁNKOVÁ, J. (2016) Efektivita vzdělávací činnosti ve vysokoškolském prostředí. In TROJAN, V. et al. Přistupy k efektivitě z pohledu managementu vzdělávání. Praha: Univerzita Karlova, Pedagogická fakulta.

ŠIKÝŘ, M. (2014). Nejlepší praxe v ř́zení lidských zdrojů. Praha: Grada Publishing.

ŠIKÝŘ, M., BOROVEC, D. \& LHOTKOVÁ, I. (2012). Personalistika v ř́zení školy. Praha: Wolters Kluwer ČR.

TURECKIOVÁ, M. (2009). Rozvoj a ř́zení lidských zdrojů. Praha: Univerzita Jana Amose Komenského v Praze.

TURECKIOVÁ, M. (2013). Edukace rídících pracovníků ve školství. In TROJAN, V., SVOBODA, P. (Eds.) Sborník príspěvků: 2. ročník mezinárodni vědecké konference školského managementu. Praha: Univerzita Karlova v Praze, Pedagogická fakulta, Centrum školského managementu.

TURECKIOVÁ, M. (2016). Strategický přístup ke vzdělávání a rozvoji pracovníků vzdělávacích organizací. In TROJAN, V. et al. Př́stupy $k$ efektivitě z pohledu managementu vzdělávání. Praha: Univerzita Karlova, Pedagogická fakulta.

URBAN, J. (2003). Řizení lidí v organizacích. Personální rozměr managementu. Praha: ASPI.

VETEŠKA, J. \& TURECKIOVÁ, M. (2008). Kompetence ve vzdělávání. Praha: Grada Publishing.

VETEŠKA, J. (2010). Kompetence ve vzdělávání dospělých: pedagogické, andragogické a sociální aspekty. Praha: Univerzita Jana Amose Komenského v Praze.

VOJTOTIČ, S. (2011). Koncepce personálního ř́zení a řízení lidských zdrojü. Praha: Grada Publishing. 